\title{
Metabolic evaluation of young women with congenital adrenal hyperplasia
}

\author{
Avaliação metabólica em mulheres jovens \\ com hiperplasia adrenal congênita
}

Gabrielle Sormanti Schnaider-Rezek ${ }^{1,2}$, Sofia Helena Valente de Lemos-Marini', Maria Tereza Matias Baptista', Gil Guerra-Júnior', André Moreno Morcillo', Maricilda Palandi de Mello³, Laurione Cândido de Oliveira ${ }^{4}$, Lilia D'Souza-Li'

1 Department of Pediatrics, Pediatric Endocrinology Unit and Center for Investigations in Pediatric (CIPED), Faculdade de Ciências Médicas (FCM), Universidade Estadual de Campinas (Unicamp), Campinas, SP, Brazil 2 Program in Child and Adolescent Health, FCM, Unicamp, Campinas, SP, Brazil ${ }^{3}$ Center of Molecular Biology and Genetic Engineering (CBMEG), Unicamp, Campinas, SP, Brazil ${ }^{4}$ Laboratory of Physiology, Clinical Hospital, Unicamp Campinas, SP, Brazil

\section{Correspondence to: \\ Lília D'Souza-Li \\ Centro de Investigação em Pediatria (CIPED), \\ Faculdade de Ciências Médicas, Universidade Estadual de Campinas Rua Tessália Vieira de Camargo, 126 Cidade Universitária "Zeferino Vaz" 13083-887 - Campinas, SP, Brazil \\ Idesouza@fcm.unicamp.br}

Received on 7/Oct/2011 Accepted on 21/Oct/2011

\begin{abstract}
Objective: To evaluate insulin resistance and lipid profile in women with congenital adrenal hyperplasia (CAH) caused by classical 21-hydroxylase deficiency (21OHD), and their association with body mass index (BMI) and corticosteroid dosage. Subjects and methods: We assessed $\mathrm{BMI}$, waist circumference, current glucocorticoid dosage, glucose, insulin and lipid profile in eighteen young women (mean \pm SD, $19.3 \pm 3.0$ years) with $210 \mathrm{HD}$ CAH. Results: BMI was normal in 12 patients, 5 of them were overweight, and 1 was obese. Waist circumference was high in 7 patients. Fasting insulin and HOMA-IR were elevated in seven and eight patients, respectively. Total cholesterol and triglycerides were high in only two patients, and HDL-cholesterol was low in four. Insulin resistance was not associated with BMI, waist circumference or glucocorticoid dose. Conclusions: Young women with 210HD CAH had infrequent dyslipidemia, but had a higher prevalence of insulin resistance and central obesity, that were independent of BMI or corticosteroid dosage. Arq Bras Endocrinol Metab. 2011;55(8):646-52
\end{abstract}

\section{Keywords}

Congenital adrenal hyperplasia; insulin resistance; dyslipidemia; obesity

\section{RESUMO}

Objetivo: Avaliar a presença de resistência insulínica e dislipidemia em mulheres com hiperplasia adrenal congênita (HAC) por deficiência da 21-hidroxilase (210HD) e investigar a associação com índice de massa corporal (IMC) e dose de glicocorticoide prescrita. Pacientes e métodos: Em 18 mulheres jovens (média \pm DP, 19,3 \pm 3,0 anos), avaliamos IMC, circunferência abdominal, dose de glicocorticoide, glicemia, insulinemia e perfil lipídico. Resultados: O IMC foi normal em 12 pacientes; 5 apresentavam sobrepeso e 1 apresentou obesidade. Circunferência abdominal estava aumentada em 7 pacientes. Insulinemia de jejum e HOMA-IR estavam elevados em 7 e 8 pacientes, respectivamente. Apenas 2 pacientes apresentaram aumento de colesterol total ou de triglicérides e 4, diminuição dos níveis de HDL-colesterol. Resistência insulínica não apresentou associação com IMC, circunferência abdominal ou dose de glicocorticoide prescrita. Conclusão: Mulheres jovens com CAH 210HD apresentaram pouca dislipidemia, mas tiveram alta prevalência de resistência insulínica e obesidade central, independentemente do IMC e da dose de glicocorticoide prescrita. Arq Bras Endocrinol Metab. 2011;55(8):646-52

Descritores

Hiperplasia adrenal congênita; resistência insulínica; dislipidemia; obesidade

\section{INTRODUCTION}

$\mathrm{C}$ Tongenital adrenal hyperplasia $(\mathrm{CAH})$, in the majority of the cases, is caused by 21 -hydroxylase deficiency (2lOHD) (1). The classic form of 2lOHD is divided into two variants: the simple virilizing form (SV; characterized by deficient cortisol production and increased androgen production), and the salt-wasting 
form (SW). In addition to the same symptoms observed in $\mathrm{SV}$, a deficiency in aldosterone production may occur (2). The treatment of the classic form of $21 \mathrm{OHD}$ is designed to effectively replace cortisol and aldosterone, and to control symptoms of excess androgen by using the lowest possible dose of glucocorticoid. However, if this replacement does not correctly meet individual physiological requirements, patients can develop either hyperandrogenism or hypercortisolism. The former can lead to early puberty, short stature, high lean mass and infertility, while the latter may lead to short stature, insulin resistance, osteoporosis, high fat mass and obesity (2-3).

There are few studies of the effects of adrenal hypofunction and early exposure to hyperandrogenism on insulin secretion and obesity (1). These effects are too uncertain to allow the general practitioner, who treats patients with $\mathrm{CAH}$, to make decisions based on therapeutic principles. Studies in animal models suggest that prenatal and neonatal androgen exposure increase adiposity and insulin resistance, and alters lipolysis in adulthood, indicating that androgens may induce metabolic reprogramming (4-7). Transient androgen exposure, early in the reproductive life of rats, may have a prolonged adverse effect on insulin sensitivity (6-7). Interventions that avoid androgen exposure in early in life could prevent long term metabolic consequences (4).

Adult patients with classical CAH have a higher frequency of obesity, visceral adiposity, hyperinsulinism, insulin resistance and hyperandrogenism, compared with normal individuals $(1,8-20)$. However, it is not clear whether hyperinsulism is due to increased obesity in these patients, or if it is inherent to the disorder itself. Adrenomedullary dysfunction and intermittent hypercortisolism are linked to these abnormalities, which predispose these patients to a higher risk of metabolic syndrome and atherosclerosis (1,8-20).

The growing need to prevent chronic cardiovascular diseases during childhood increases the importance of understanding lipid metabolism and insulin resistance of CAH patients, since cardiovascular diseases are presently the main cause of morbidity and mortality in developed countries $(21,22)$.

The aims of this study were to evaluate insulin resistance and lipid profile in young women with classical $21 \mathrm{OHD} \mathrm{CAH}$, and to analyze the associations between insulin resistance, body mass index (BMI), dyslipidemia and glucocorticoid doses.

\section{SUBJECTS AND METHODS}

We evaluated young adult women, between 14 and 23 years old, with classical 21OHD CAH, breasts Tanner stage 4 or 5 , and who had reached their final height (defined as growth velocity lower than $1 \mathrm{~cm}$ in the previous year). Only patients with complete anthropometric and laboratory evaluations were included in this study. This was a cross sectional study, and it was approved by the local Ethics Committee board beforehand.

Since initial care in the Pediatric Endocrinology outpatient clinic of the Clinical Hospital at Unicamp, the same doctor treated all the patients using a dietetic and behavioral therapeutic approach. None of the patients used hypoglycemic or hypolipidemic drugs. Diagnosis of $21 \mathrm{OHD} \mathrm{CAH}$ was determined during the first year of life by clinical features and hormonal measurements, and it was confirmed later on by molecular genetic testing $(23,24)$.

Patients were evaluated for weight, height, arterial blood pressure, waist circumference, Tanner pubertal stage, and their current type of glucocorticoid replacement. We used the BMI criteria of the World Health Organization (WHO), which considers normal weight from 18.5 to $24.9 \mathrm{~kg} / \mathrm{m}^{2}$, overweight from 25 to 29.9 $\mathrm{kg} / \mathrm{m}^{2}$, and obesity $\geq 30 \mathrm{~kg} / \mathrm{m}(25)$. Waist circumference $\geq 80 \mathrm{~cm}$ was considered increased, according to the International Diabetes Federation (IDF) (26). Abnormal blood pressure was defined as $\geq 130 \mathrm{mmHg}$ for systolic pressure, and $\geq 85 \mathrm{mmHg}$ for diastolic pressure, according to the IDF, the American Heart Association (AHA), and the Brazilian Society of Cardiology (SBC) (26-28).

After a 12-hour fast, a serum sample was collected and glucose, insulin, total cholesterol, cholesterol fractions, and triglycerides were measured. Serum insulin was analyzed by chemiluminescence (Siemens Healthcare Diagnostics Products kit and Immulite Analyzer $\left.^{(\mathrm{R})}\right)$. The inter-assay coefficient of variation was $6.4 \%$, with $8.5 \%$ detectable cross-reaction with proinsulin, and with no cross-reaction with C-peptide or glucagon. Normal insulin range was defined as 6.0 to 28.4 $\mu \mathrm{U} / \mathrm{mL}$.

The other variables were measured by colorimetric assays. Total cholesterol levels above $200 \mathrm{mg} / \mathrm{dL}$, LDL-cholesterol higher than $160 \mathrm{mg} / \mathrm{dL}$ and triglycerides over $150 \mathrm{mg} / \mathrm{dL}$ were defined as high, according to the SBC (28). For HDL-cholesterol, values below $50 \mathrm{mg} / \mathrm{dL}$ were considered low (27). 
To evaluate insulin resistance (IR) we used both fasting insulin and the homeostasis model assessment (HOMA-IR) (29). We considered insulin resistance as fasting insulin $\geq 15 \mu \mathrm{U} / \mathrm{mL}$, for the established assay (30). We used the HOMA-IR cutoff point for Brazilian populations, which considers insulin resistance results over 2.71 (31-33).

To calculate current glucocorticoid doses, we transformed prednisone, prednisolone and dexamethasone into hydrocortisone equivalents, by multiplying the prednisone or prednisolone dose by 4 and dexamethasone by 24 (34). These hydrocortisone equivalents were divided by body surface area $\left(\mathrm{m}^{2} \mathrm{BS}\right)$ for comparison. We defined two dose groups, $\leq 20 \mathrm{mg} / \mathrm{m}^{2} \mathrm{BS} /$ day, and above this level, since many studies use this cutoff point to define high treatment doses (1-3).

Metabolic syndrome was identified if the patient presented central obesity plus two or more of the following conditions: high triglycerides, low HDL-cholesterol level, systemic hypertension (or use of any antihypertensive drug), and high fasting glucose level (or previously diagnosed type 2 diabetes mellitus) (26).

Data were recorded and analyzed by SPSS ${ }^{(\mathrm{R})}$ version 16.0 for Windows ${ }^{(\mathrm{R})}$ (SPSS Inc., Chicago, IL, USA). For continuous variables, means, medians, standard deviations (SD), minimum and maximum values were determined. To evaluate the association between the variables, we defined binomial categories and used the Fisher's two-sided exact test. The correlation between continuous variables was analyzed by Spearman's rank correlation coefficient. We used $\mathrm{p}<0.05$ as the significance level for all analyses.

\section{RESULTS}

Eighteen patients, from 14.5 to 23.3 years old, fulfilled the inclusion criteria. The mean time of follow-up was $18.2 \pm 3.0$ years (range, 13.2-22.4 years). Ten patients had the salt-wasting form of $\mathrm{CAH}$, and 8 had the non-salt-wasting form or simple virilizing form (Table 1 ). Mean final height was $156.0 \mathrm{~cm}$.

BMI was normal in 12 patients, 5 women were overweight and only one was obese. Waist circumference was increased in 7 patients. Systolic blood pressure ranged from 80.0 to $130.0($ mean $\pm S D, 105.0 \pm 12.9$ ), and was high in one patient; diastolic pressure ranged from 50.0 to 90.0 (mean \pm SD, $69.4 \pm 10.6$ ), and was high in another patient. Waist circumference was significantly associated with BMI (Fisher's exact test, $\mathrm{p}=0.013) ; 5$ out of the 6 patients with excess weight had increased waist circumference, while only 2 out of 12 patients with normal weight had increased waist circumference.

Total cholesterol was high in 2 patients, HDL-cholesterol low in 4 and LDL-cholesterol was uniformly normal. Triglycerides were high in 2 patients. Fasting glucose was normal in all patient; 7 patients had high levels of fasting insulin, and 8 had high HOMA-IR.

Only 2 of the 7 patients with increased waist circumference had high fasting insulin levels, and 3 had high HOMA-IR. Of the 11 patients with normal waist circumference, 5 had high fasting insulin levels, and 5 had high HOMA-IR (Table 2). Therefore, there was no association between waist circumference and insulin resistance (fasting insulin, $\mathrm{p}=0.637$; HOMA-IR, $\mathrm{p}=$ 1.0). Concerning insulin resistance, 3 out of 6 patients with excess weight had high fasting insulin level, and 4 had high HOMA-IR; in contrast, among the 12 patients with normal weight, 4 had high fasting insulin, and 4 had high HOMA-IR. However, insulin resistance was not associated with excess weight, and it was independent of BMI (fasting insulin, $\mathrm{p}=0.627$; HOMA-IR, $\mathrm{p}=0.321$ ).

The types of glucocorticoids used on the day of blood sample collection were: 5 patients were taking hydrocortisone, 8 were taking prednisone or prednisolone, and 5 were taking dexamethasone. Glucocorticoid doses, converted to hydrocortisone equivalents, ranged from 6.67 to $29.25 \mathrm{mg} / \mathrm{m}^{2} \mathrm{BS} /$ day (mean \pm , $18.3 \pm 6.1$ ). Seven patients were taking doses above 20 $\mathrm{mg} / \mathrm{m}^{2} \mathrm{BS} /$ day, and 11 were taking doses below this value. The presence of dyslipidemia in this group was independent of the current glucocorticoid dose (total cholesterol, $\mathrm{p}=0.497$; HDL-cholesterol, $\mathrm{p}=1.0$; triglycerides, $\mathrm{p}=1.0$ ). There was no association between the current glucocorticoid dose and excess weight, increased waist circumference, or high blood pressure (excess weight, $\mathrm{p}=1.0$; waist circumference, $\mathrm{p}=$ 1.0; systolic blood pressure, $\mathrm{p}=0.389$; diastolic blood pressure, $\mathrm{p}=1.0$; Table 3 ). There was no association between glucocorticoid dose and insulin resistance, either (fasting insulin, $\mathrm{p}=1.0$; HOMA-IR, $\mathrm{p}=0.630$, Table 3), and no correlation between glucocorticoid dose and HOMA-IR (Spearman correlation coefficient $=0.145 ; \mathrm{p}=0.567$ ).

According to the criteria of the International Diabetes Federation (IDF), none of the patients had metabolic syndrome. 
Table 1. Data of 18 young women with the classical form of 21-hydroxylase deficiency

\begin{tabular}{|c|c|c|c|c|c|c|c|c|c|c|c|}
\hline $\begin{array}{l}\text { Patient } \\
\text { number }\end{array}$ & $\begin{array}{c}\text { Age } \\
\text { years }\end{array}$ & $\begin{array}{c}\mathrm{BMI} \\
\mathrm{kg} / \mathrm{m}^{2}\end{array}$ & $\begin{array}{c}\text { Hydro } \\
\text { equivalent } \\
\mathrm{mg} / \mathrm{m}^{2} \mathrm{BS} / \mathrm{day}\end{array}$ & $\begin{array}{c}\text { Waist } \\
\text { cm }\end{array}$ & $\begin{array}{l}\text { Glucose } \\
\mathrm{mg} / \mathrm{dL}\end{array}$ & $\begin{array}{l}\text { Insulin } \\
\mu \mathrm{UI} / \mathrm{mL}\end{array}$ & HOMA IR & $\begin{array}{c}\text { Cholesterol } \\
\mathrm{mg} / \mathrm{dL}\end{array}$ & $\begin{array}{c}\mathrm{HDL} \\
\mathrm{mg} / \mathrm{dL}\end{array}$ & $\begin{array}{c}\mathrm{LDL} \\
\mathrm{mg} / \mathrm{dL}\end{array}$ & $\begin{array}{l}\text { Triglycerides } \\
\text { mg/dL }\end{array}$ \\
\hline $1^{*}$ & 18.0 & 29.4 & 19.9 & 81.0 & 79.0 & 11.3 & 2.2 & 205.0 & 72.0 & 117.0 & 82.0 \\
\hline $2^{\star \star}$ & 22.5 & 19.7 & 17.5 & 76.0 & 77.0 & 8.4 & 1.6 & 184.0 & 75.0 & 93.0 & 78.0 \\
\hline $3^{*}$ & 22.4 & 26.9 & 10.0 & 90.0 & 75.0 & 9.7 & 1.8 & 265.0 & 67.0 & 152.0 & 229.0 \\
\hline $4^{\star \star}$ & 18.8 & 25.1 & 24.7 & 100.0 & 78.0 & 16.3 & 3.1 & 154.0 & 38.0 & 99.0 & 86.0 \\
\hline $5^{\star \star}$ & 16.9 & 24.1 & 18.5 & 75.0 & 78.0 & 4.7 & 0.9 & 165.0 & 59.0 & 88.0 & 89.0 \\
\hline $6^{\star *}$ & 22.0 & 19.7 & 20.3 & 68.2 & 77.0 & 7.2 & 1.4 & 174.0 & 72.0 & 92.0 & 51.0 \\
\hline $7^{*}$ & 15.7 & 19.1 & 16.2 & 73.0 & 71.0 & 17.6 & 3.1 & 153.0 & 60.0 & 78.0 & 73.0 \\
\hline $8^{*}$ & 15.6 & 20.2 & 24.6 & 71.0 & 72.0 & 8.1 & 1.4 & 177.0 & 81.0 & 88.0 & 42.0 \\
\hline $9^{\star *}$ & 17.3 & 24.7 & 21.8 & 81.5 & 69.0 & 8.6 & 1.5 & 167.0 & 61.0 & 96.0 & 48.0 \\
\hline $10^{\star *}$ & 23.3 & 15.7 & 18.5 & 66.0 & 79.0 & 6.0 & 1.2 & 156.0 & 67.0 & 73.0 & 81.0 \\
\hline $11^{*}$ & 17.5 & 27.5 & 23.6 & 81.0 & 92.0 & 14.2 & 3.2 & 171.0 & 35.0 & 95.0 & 207.0 \\
\hline $12^{\star \star}$ & 21.9 & 22.5 & 10.7 & 71.0 & 87.0 & 33.8 & 7.3 & 160.0 & 67.0 & 81.0 & 60.0 \\
\hline $13^{\star \star}$ & 16.2 & 23.5 & 29.2 & 73.0 & 80.0 & 24.1 & 4.8 & 126.0 & 54.0 & 62.0 & 50.0 \\
\hline $14^{* \star}$ & 22.2 & 22.5 & 17.3 & 68.0 & 86.0 & 5.17 & 1.1 & 144.0 & 32.0 & 99.0 & 64.0 \\
\hline $15^{\star}$ & 14.4 & 31.1 & 8.7 & 92.0 & 81.0 & 23.0 & 4.6 & 172.0 & 59.0 & 109.0 & 45.0 \\
\hline $16^{*}$ & 22.1 & 24.9 & 6.7 & 85.0 & 79.0 & 4.6 & 0.9 & 155.0 & 83.0 & 48.0 & 118.0 \\
\hline $17^{\star \star}$ & 18.5 & 25.5 & 18.5 & 78.0 & 68.0 & 19.7 & 3.3 & 158.0 & 47.0 & 95.0 & 80.0 \\
\hline $18^{*}$ & 22.7 & 21.0 & 22.7 & 70.0 & 78.0 & 18.3 & 3.5 & 179.0 & 69.0 & 100.0 & 51.0 \\
\hline mean $\pm S D$ & $19.3 \pm 3$ & $23.5 \pm 3.9$ & $18.3 \pm 6.1$ & $77.8 \pm 9.3$ & $77.9 \pm 6.4$ & $13.4 \pm 8.1$ & $2.6 \pm 1.7$ & $170.3 \pm 29.2$ & $61 \pm 14.9$ & $92.5 \pm 22$ & $85.2 \pm 52.2$ \\
\hline $\min -\max$ & $14.4-23.3$ & $15.7-31.1$ & $6.7-29.2$ & $66.0-100.0$ & $65.0-92.0$ & $4.6-33.8$ & $0.9-7.3$ & $126.0-265.0$ & $32.0-83.0$ & $48.0-152.0$ & $42.0-229.0$ \\
\hline
\end{tabular}

*: Non salt-wasting form; **: Salt-wasting form; BMI: body mass index; HOMA-IR: Homeostasis model assessment; hydro equivalent: hydrocortisone equivalent dosage.

Table 2. Insulin resistance according to excess weight and glucocorticoid dosage in 18 young women with 21-hydroxylase deficiency

\begin{tabular}{|c|c|c|c|c|}
\hline & \multicolumn{2}{|c|}{$\begin{array}{c}\text { Fasting insulin } \\
(\geq 15 \mu \mathrm{U} / \mathrm{mL})\end{array}$} & \multicolumn{2}{|c|}{$\begin{array}{l}\text { HOMA-IR } \\
(\geq 2.71)\end{array}$} \\
\hline & Normal & Resistant & Normal & Resistant \\
\hline Normal waist circumference & 6 & 5 & 6 & 5 \\
\hline Increased waist circumference & 5 & 2 & 4 & 3 \\
\hline Excess weight & 3 & 3 & 2 & 4 \\
\hline No excess weight & 8 & 4 & 8 & 4 \\
\hline$\leq 20 \mathrm{mg} / \mathrm{m}^{2} \mathrm{BS} /$ Day & 7 & 4 & 7 & 4 \\
\hline$>20 \mathrm{mg} / \mathrm{m}^{2} \mathrm{BS} /$ Day & 4 & 3 & 3 & 4 \\
\hline Total & 11 & 7 & 10 & 8 \\
\hline
\end{tabular}

There was no association between waist circumference or excess weight or glucocorticoid dose and insulin resistance. Fisher's exact test: fasting insulin $\mathrm{x}$ waist circumference, $\mathrm{p}=0.637$; fasting insulin $x$ excess weight, $p=1.0$; fasting insulin $x$ glucocorticoid dose. $p=1.0$; HOMA-IR $x$ waist circumference, $p=1.0$; HOMA-IR $x$ excess weight, $p=0.321 ;$ HOMA-IR $x$ glucocorticoid dose $p$ $=0.630$.

\section{DISCUSSION}

There are few studies of metabolic disorders in young women with $\mathrm{CAH}$ (1). Our study addressed the question of whether risk factors for either cardiovascular disease or type 2 diabetes mellitus are directly associated
Table 3. Frequency of abnormal clinical and laboratory evaluations according to glucocorticoid dose in 18 young women with classical 21-hydroxylase deficiency

\begin{tabular}{lccc}
\hline & $\begin{array}{c}\mathbf{2 0} \mathbf{~ m g /} \\
\mathbf{m}^{\mathbf{2}} \mathbf{B S} / \mathbf{d a y}\end{array}$ & $\begin{array}{c}\mathbf{> 2 0} \mathbf{~ m g} / \\
\mathbf{m}^{2} \mathbf{B S} / \mathbf{d a y}\end{array}$ & $\mathbf{p}$ value* \\
\hline Excess weight & 4 & 2 & $p=1.0$ \\
Increased waist circumference & 4 & 3 & $p=1.0$ \\
High systolic blood pressure & 0 & 1 & $p=0.389$ \\
High fast insulin & 4 & 3 & $p=1.0$ \\
High HOMA-IR & 4 & 4 & $\mathrm{p}=0.63$ \\
High total cholesterol & 2 & 0 & $\mathrm{p}=0.497$ \\
Low HDL-cholesterol & 2 & 2 & $\mathrm{p}=1.0$ \\
High triglycerides & 1 & 1 & $\mathrm{p}=1.0$ \\
\hline
\end{tabular}

*: Fisher's exact test.

with $\mathrm{CAH}$ itself, or related to other diseases frequently found in these patients, i.e. obesity, dyslipidemia, hypertension, and excess glucocorticoid (8-20).

Unlike the great majority of published studies on patients with $\mathrm{CAH}$, we did not find a high propensity 
for obesity or excess weight (8-12,14-15,18-19). We believe that this finding was due to the rigorous clinical management of our patients since diagnosis; they were followed up by the same doctor, and they received guidance that emphasized adequate nutrition and adherence to medication.

In the majority of studies of adult females with $\mathrm{CAH}$, patients were either taking excessive doses of glucocorticoid in order to control the inherent hyperandrogenism (8), or they had not been previously treated $(14,19)$. In contrast, our study group was treated with glucocorticoid replacement since their first months of life. Studies on children and adolescents with $\mathrm{CAH}$ had small number of patients and, different from our study, their patients showed a wide age range and pubertal status, making comparisons with our group difficult $(15,18)$.

Studies with animal models suggest that prenatal and neonatal exposure to androgens results in increased adiposity, insulin resistance and alterations in lipolysis in adulthood, indicating that androgens may induce metabolic reprogramming (4-7).

Studies with sheep showed that fetal hyperandrogenism induces polycystic ovaries, and is associated with delayed intrauterine growth; rapid postnatal growth recovery - both well-known risk factors for insulin resistance - carbohydrate intolerance; and type 2 diabetes in adulthood (7). In a hyperandrogenism model using female Rhesus monkeys, early prenatal introduction of testosterone produced an increase in postnatal adrenal androgens, causing hyperandrogenism similar to that observed in polycystic ovarian syndrome (PCOS) (5). In addition, metabolic changes were observed including aberrant distribution of adipose tissue, defects in insulin secretion, and response and accumulation of visceral fat, independent of obesity (5-7).

Hyperinsulinism and excess androgen may promote central body fat distribution, as we observed in our study. However, weight and BMI are not sensitive enough to detect redistribution of body fat. The prevalence of excessive waist circumference (7 of 18 patients), indicated that the changes we found in body composition were probably inherent to $\mathrm{CAH}$, suggesting that hyperandrogenism was responsible for central fat accumulation. Stikkelbroeck and cols. (12) evaluating body composition in patients with $\mathrm{CAH}$ using Dual-emission $\mathrm{X}$-ray absorptiometry, found lean body mass similar to controls matched for age, but a significantly increased trunk fat mass. However, they found a high incidence of excess weight ( 8 of 12) while, in our study, only 3 of 18 patients had a BMI above $25 \mathrm{mg} / \mathrm{m}^{2}$. Gonçalves and cols. (11) studied 16 patients with 21-hydroxilase deficiency using bioelectrical impedance, and also detected a higher proportion of fat mass compared to their controls matched for age, with no tendency towards greater BMI. Although this study included some of patients from our study, the age of the patients was extremely variable ( 8 to 18 years old), and it was not possible to exclude gender and puberty variability in this population.

We found a high frequency of insulin resistance. Seven of 18 patients had high fasting insulin levels, and 8 had high HOMA-IR, independent of BMI and of current dose of glucocorticoid. This suggests that insulin resistance was due to the disease itself. This interpretation is reinforced by studies on newly diagnosed CAH patients that show insulin resistance prior to glucocorticoid treatment $(14,19)$. Moreover, in our data, mean HOMA-IR was even greater than that of Chinese women studied by Zhang (19) (mean \pm SD, $2.6 \pm 1.7$ versus $1.81 \pm 0.99$, respectively). In a Turkish study of 18 untreated women with the non-classical form of CAH, Saygili and cols. (14) also found elevated HOMA-IR (mean $\pm \mathrm{SD}, 3.2 \pm 0.8$ ), which was greater than that of controls matched by BMI. Arlt and cols. (8), in a multicenter study of 199 women with $\mathrm{CAH}$, found a high frequency of insulin resistance, increased waist circumference, and a tendency towards diabetes type 2 and gestational diabetes. Different from our patients, the majority of these women were obese (52.2\%) and had clinical signs of excess glucocorticoid (stretch marks, osteoporosis and suppressed androgen levels). In addition, they did not report molecular confirmation of $\mathrm{CAH}$, and the patients had been treated in 17 different study centers. Despite the increased risk of diabetes type 2, evident in our data by insulin resistance and excessive waist circumference, none of our patients had metabolic syndrome, since we found high blood pressure or dyslipidemia in few patients (35). This data is similar to that of Falhamar and cols.: they did not find dyslipidemia in 27 patients between 18 and 30 years of age with $\mathrm{CAH}$.

Sartorato and cols. (16) showed that insulin resistance per se is capable of causing atherosclerotic disease. Hence, we can infer that patients with $\mathrm{CAH}$ are susceptible to cardiovascular disease, as well as at increased risk for type 2 diabetes mellitus. Our findings suggest that rigorous treatment, with both medication and die- 
tary-behavioral guidance, when provided from the first year of life, reduces the risk of some of the components of the metabolic syndrome.

In conclusion, this group of patients with classical 21OHD had infrequent dyslipidemia, but had a higher incidence of insulin resistance and central obesity that were independent of BMI and glucocorticoid doses.

Acknowledgements: the authors would like to thank Dr. Taylor Brandão Schnaider for supporting this research, and Dr. Roger Frigério Castilho for his assistance with laboratory measurements.

Disclosure: no potential conflict of interest relevant to this article was reported.

\section{REFERENCES}

1. Speiser PW, Azziz R, Baskin LS, Ghizzoni L, Hensle TW, Merke DP, et al. Congenital adrenal hyperplasia due to steroid 21-hydroxylase deficiency: an endocrine society clinical practice guideline. $\mathrm{J}$ Clin Endocrinol Metab. 2010; 95(9):4133-60.

2. Labarta JI, Bello E, Ruiz-Echarri M, Rueda C, Martul P, Mayayo E, et al. childhood-onset congenital adrenal hyperplasia: long-term outcome and optimization of therapy. J Pediatr Endocrinol Metab. 2004;17(3):411-22.

3. Charmandari E, Johnston A, Brook CG, Hindmarsh PC. Bioavailability of oral hydrocortisone in patients with congenital adrenal hyperplasia due to 21-hydroxylase deficiency. J Endocrinol. 2001;169(1):65-70.

4. Cameron N, Demerath EW. Critical periods in human growth and their relationship to diseases of aging. Am J Phys Anthropol. 2002;Suppl 35:159-84.

5. Abbott DH, Barnett DK, Bruns CM, Dumesic DA. Androgen excess fetal programming of female reproduction: a developmental etiology for polycystic ovary syndrome? Hum Reprod Update. 2005;11(4):357-74.

6. Recabarren SE, Sir-Petermann T, Maliqueo M, Lobos A, Rojas-García P. La exposición prenatal a andrógenos como factor de reprogramación fetal. Rev Med Chil. 2006;134(1):101-8.

7. Xita N,Tsatsoulis A. Fetal origins of the metabolic syndrome. Ann NY Acad Sci. 2010;1205:148-55.

8. Arlt W, Willis DS, Krone N, Doherty EJ, Hahner S, Han TS, et al. Health status of adults with congenital adrenal hyperplasia: a cohort study of 203 patients. J Clin Endocrinol Metab. 2010;95(11):5110-21.

9. Cornean RE, Hindmarsh PC, Brook CG. Obesity in 21-hydroxylase deficient patients. Arch Dis Child. 1998;78(3):261-3.

10. Isguven P, Arslanoglu I, Mesutoglu N, Yildiz M, Erguven M. Bioelectrical impedance analysis of body fatness in childhood congenital adrenal hyperplasia and its metabolic correlates. Eur $\mathrm{J}$ Pediatr. 2008;167(11):1263-8.

11. Gonçalves EM, Lemos-Marini SHV, Mello MP, Baldin AD, Carvalho WRG, Farias ES, et al. Body composition in females with 21-hydroxilase deficiency: comparison of anthropometric methods and bioeletric impedance in relation to a control group. Arq Bras Endocrinol Metab. 2010;54(3):274-81.

12. Stikkelbroeck NM, Oyen WJ, van der Wilt GJ, Hermus AR, Otten BJ. Normal bone mineral density and lean body mass, but increased fat mass, in young adult patients with congenital adrenal hyperplasia. J Clin Endocrinol Metab. 2003;88(3):1036-42.
13. Speiser PW, Serrat J, New MI, Gertner JM. Insulin insensitivity in adrenal hyperplasia due to nonclassical steroid 21-hydroxylase deficiency. J Clin Endocrinol Metab. 1992;75(6):1421-4.

14. Saygili F, Oge A, Yilmaz C. Hyperinsulinemia and insulin insensitivity in women with nonclassical congenital adrenal hyperplasia due to 21-hydroxylase deficiency: the relationship between serum leptin levels and chronic hyperinsulinemia. Horm Res. 2005;63(6):270-4.

15. Charmandari E, Weise M, Bornstein SR, Eisenhofer G, Keil MF, Chrousos GP, et al. Children with classic congenital adrenal hyperplasia have elevated serum leptin concentrations and insulin resistance: potential clinical implications. J Clin Endocrinol Metab. 2002;87(5):2114-20.

16. Sartorato P, Zulian E, Benedini S, Mariniello B, Schiavi F, Bilora F, et al. Cardiovascular risk factors and ultrassound evaluation of intima-media thickness at common carotids, carotid bulbs, and femoral and abdominal aorta arteries in patients with classic congenital adrenal hyperplasia due to 21-hydroxylase deficiency. $J$ Clin Endocrinol Metab. 2007;92(3):1015-8.

17. Falhammar H, Filipsson $H$, Holmdahl G, Janson PO, Nordenskjöld $A$, Hagenfeldt $K$, et al. Metabolic profile and body composition in adult women with congenital adrenal hyperplasia due to 21-hydroxylase deficiency. J Clin Endocrinol Metab. 2007;92(1):110-6.

18. Botero D, Arango A, Danon M, Lifshitz F. Lipid profile in congenital adrenal hyperplasia. Metabolism. 2000;49(6):790-3.

19. Zhang HJ, Yang J, Zhang MN, Liu CO, Xu M, Li XJ, et al. Metabolic disorders in newly diagnosed young adult female patients with simple virilizing 21-hydroxylase deficiency. Endocrine. 2010;38(2):260-5.

20. Charmandari E, Chrousos GP. Metabolic syndrome manifestations in classic congenital adrenal hyperplasia: do they predispose to atherosclerotic cardiovascular disease and secondary polycystic ovary syndrome? Ann NY Acad Sci. 2006;1083:37-53.

21. Mansur AP, Souza MFM,Timermann A, Ramires JAF.Trends of the risk of death due to circulatory, cerebrovascular, and ischemic heart diseases in 11 Brazilian capitals from 1980 to 1998. Arq Bras Cardiol. 2002;79(3):277-84.

22. McMahan CA, Gidding SS, Malcom GT, Tracy RE, Strong JP, McGill HC Jr; Pathobiological determinants of atherosclerosis in youth research group. Pathobiological determinants of atherosclerosis in youth risk scores are associated with early and advanced atherosclerosis. Pediatrics. 2006;118(4):1447-55.

23. Paulino LC, De-Araujo M, Guerra-Junior G, Lemos-Marini SHV, De-Mello MP. Mutation distribution and CYP21/C4 locus variability in Brazilian families with the classical form of the 21-hydroxylase deficiency. Acta Paediatr. 1999;88:275-83.

24. Soardi FC, Barbaro M, Lau IF, Lemos-Marini SHV, Baptista MT, Guerra-Junior G, et al. Inhibition of CYP21A2 enzyme activity caused by novel missense mutations identified in Brazilian and Scandinavian patients. J Clin Endocrinol Metab. 2008;93:2416-20.

25. World Health Organization. Body Mass Index Classification. Available in: http://apps.who.int/bmi. Genebra, 2006.

26. International Diabetes Federation. The IDF consensus worldwide definition of the metabolic syndrome. Available in: http://www. bibalex.org/supercourse/metabolic/IDF1.pdf. Bruxelas.

27. Sposito AC, Caramelli B, Fonseca FAH, Bertolami MC, Rassi-Jr A. IV Brazilian guidelines on dyslipidemia and prevention of atherosclesosis. Department of Atherosclerosis from the Brazilian Cardiology Society. Arq Bras Cardiol. 2007;88(suppl1):1-18.

28. Steinberger J, Daniels SR, Eckel RH, Hayman L, Lustig RH, McCrindle B, et al.; American Heart Association Atherosclerosis, Hypertension and Obesity in the Young Committee of the Council on Cardiovascular Disease in the Young; Council on Cardiovascu- 
lar Nursing; and Council on Nutrition, Physical Activity, and Metabolism. Progress and challenges in metabolic syndrome in children and adolescents: a scientific statement from the American Heart Association Atherosclerosis, Hypertension, and Obesity in the Young Committee of the Council on Cardiovascular Disease in the Young; Council on Cardiovascular Nursing; and Council on Nutrition, Physical Activity, and Metabolism. Circulation. 2009;119(4):628-47.

29. Matthews DR, Hosker JP, Rudenski AS, Naylor BA, Treacher DF, Turner RC. Homeostasis model assessment: insulin resistance and beta-cell function from fasting plasma glucose and insulin concentrations in man. Diabetologia. 1985;28(7):412-9.

30. Bloomgarden ZT. American Association of Clinical Endocrinologists (AACE) consensus conference on the insulin resistance syndrome: 25-26 August 2002, Washington, DC. Diabetes Care. 2003;26(4):1297-303.

31. Geloneze B, Repetto EM, Geloneze SR, Tambascia MA, Ermetice MN. The threshold value for insulin resistance (HOMA-IR) in an admixtured population IR in the Brazilian Metabolic Syndrome Study. Diabetes Res Clin Pract. 2006;72(2):219-20.

32. Geloneze B, Vasques ACJ, Stabe CFC, Pareja JC, Rosado LEPL, Queiroz EC, et al.; BRAMS Investigators. HOMA1-IR and HOMA2-IR indexes in identifying insulin resistance and metabolic syndrome - Brazilian Metabolic Syndrome Study (BRAMS). Arq Bras Endocrinol Metab. 2009;53(2):281-7.

33. Vasques AC, Rosado LE, Alfenas RCG, Geloneze B. Critical analysis on the use of the homeostasis hodel assessment (HOMA) indexes in the evaluation of the insulin resistance and the pancreatic beta cells functional capacity. Arq Bras Endocrinol Metab. 2008;52(1):32-9

34. Debono M, Price JN, Ross RJ. Novel strategies for hydrocortisone replacement. Best Pract Res Clin Endocrinol Metab. 2009;23(2):221-32.

35. Barbosa PJB, Lessa I, Almeida-Filho N, Magalhães LBNC, Araújo J. Criteria for central obesity in a Brazilian population: impact on the metabolic syndrome. Arq Bras Cardiol. 2006;87:366-73. 